\title{
Plant growth regulators: a success story in perennial ryegrass seed crops
}

\author{
R.J. CHYNOWETH ${ }^{1}$, M.P. ROLSTON ${ }^{2}$ and B.L. MCCLOY ${ }^{3}$ \\ ${ }^{I}$ Foundation for Arable Research, P.O. Box 80, Lincoln, New Zealand \\ ${ }^{2}$ AgResearch Lincoln, Private Bag 4749, Christchurch 8140, New Zealand \\ ${ }^{3}$ NZ Arable, P.O. Box 16 101, Christchurch, New Zealand \\ chynowethr@far.org.nz
}

\begin{abstract}
The introduction of the plant growth regulator trinexapac-ethyl (Moddus) has increased seed yields in perennial ryegrass (Lolium perenne) by up to $50 \%$ in New Zealand. Application rates from ten trials have confirmed that approximately $1.6 \mathrm{l} / \mathrm{ha}$ are optimum. Yield increases are a result of increased harvest index and better dry matter partitioning to the harvested parts. The resulting changes in harvest components include increasing seed head density and seeds per spikelet (better seed retention) associated with delayed lodging.
\end{abstract}

Keywords: Lolium perenne, lodging, Moddus, seeds/spikelet, trinexapac-ethyl

\section{Introduction}

There is a 30 year history of trials with plant growth regulators (PGRs) in perennial ryegrass (Lolium perenne L.) seed crops (e.g., Hebblethwaite et al. 1980; Hampton \& Hebblethwaite 1985). Early work revolved around the use of paclobutrazol (PP333) which increased seed yield by 30 to $130 \%$ (Hampton \& Hebblethwaite 1985). However paclobutrazol has soil residual properties which may result in yield reductions in some following crops and it was not registered for use on perennial ryegrass in New Zealand. Chlormequat chloride (CCC) was applied to grass seed crops by growers during the 1990s with yield advantages in plots shown to range from 34-43\% (Hampton 1986). However grower adoption was limited. The introduction of trinexapac-ethyl (Moddus ${ }^{\circledR}$ ), a foliar absorbed PGR, revolutionised grass seed yields in New Zealand with average seed yield increases of $50 \%$ common
(Rolston et al. 2004). These results are similar to those achieved by Hebblethwaite et al. (1978) who recorded a $40 \%$ yield increase when lodging was prevented using wires. Similar results with Moddus have been achieved elsewhere in the world (e.g., Chastain et al. 2003) but application rates used by growers in the United States of America are often lower than those applied in New Zealand. Plant growth regulators are applied with the goal of reducing lodging and achieving better pollination, seed set and solar radiation use. It is currently 'best practice' for New Zealand growers to apply between 0.8 and 1.6 1/ha of Moddus to perennial ryegrass seed crops with the aim of delaying lodging. Moddus activity is greatest when applied at Zadoks growth stage (GS) 32 (average of all tillers) (Zadoks 1974). Its mode of action is to inhibit the production of gibberellic acid (Rademacher 2000), which shortens and thickens the stem, leading to either reductions in total lodging or a delay in lodging. Moddus may also have an influence on reproductive tiller survival (Borm \& van den Berg 2008), possibly through reduced shading of later developing tillers (Rolston et al. 2007a) but does not affect above ground dry weight or spikelet number (FAR unpublished data 2000; Silberstein et al. 2003). The overall effect of Moddus is an increase in the number of seeds produced per spikelet (Chastain et al. 2003; Rolston et al. 2007a).

In New Zealand, Moddus is applied to greater than 95 percent of ryegrass seed crops (Rolston et al. 2004) at rates that range up to approximately $1.6 \mathrm{l} / \mathrm{ha}$. However growers often comment on variable responses which appear to be related to 
differences in crop bulk at the time of Moddus application.

This paper reports on 10 years of field trials with Moddus PGR in New Zealand.

\section{Methods}

Various rate response trials were carried out between 1999 and 2008 with Moddus (250 g trinexapac-ethyl/1).

\section{Rate trials}

In the 2005-2008 trials a randomised complete block design with four replicates was used for all trials. Moddus application rates ranged from 0-3.2 1/ha with a number of perennial ryegrass cultivars: Assure, 'Grasslands Nui', Aries, Bronsyn, 'Grasslands Hillary', Divine, 'Grasslands Impact' and Quartet. All trials were in grower paddocks and received best management practices regarding nitrogen, weed, pest and disease management inputs. At approximately $40 \%$ seed moisture content a $1.7 \mathrm{~m}$ swath was cut from the centre of all plots with either a disc mower or a modified plot windrower. Seed was then harvested with a plot combine at $12 \%$ seed moisture content. Seed samples were machine dressed on a small-scale air-screen separator to achieve a $1^{\text {st }}$ Generation seed purity standard and converted to a yield/ha.

Detailed methods and results have been reported for data prior to 2004 by Rolston et al. (2004)

\section{Interaction trials}

In the 2007/08 season two interaction trials investigated the response of Moddus to spring nitrogen and closing date. The trials were located in mid-Canterbury. Plots were $3.2 \mathrm{~m} \mathrm{x} 10 \mathrm{~m}$ long. There were four replicates of treatments in a completely randomised block design. The trials were harvested using the same method outlined in the rate trials above. Lodging was recorded at weekly intervals by visual assessment of percentage of the plot lodged. Intercepted photosynthetically active radiation (PAR) was measured at anthesis using a linear PAR ceptometer with an 80 $\mathrm{cm}$ quantum sensor with 80 independent sensors spaced $1 \mathrm{~cm}$ apart. These sensors measure PAR in the 400-700 nm waveband and display PAR in units of $\mu \mathrm{E} / \mathrm{sec} / \mathrm{m}^{2}$ with $1 \mu \mathrm{E} / \mathrm{sec} / \mathrm{m}^{2}$ resolution.

Nitrogen was applied as urea at four rates, in $50 \mathrm{~kg} \mathrm{~N} / \mathrm{ha}$ steps from 64 to $214 \mathrm{~kg} \mathrm{~N} / \mathrm{ha}$ in a split application giving five total $\mathrm{N}$ (applied + mineral N) treatments from 36 to $250 \mathrm{~kg}$ N/ha on cultivar 'Grasslands Hillary', which has a similar flowering date to 'Grasslands Nui' perennial ryegrass. Mineral $\mathrm{N}$ and mineralisable (incubation) $\mathrm{N}$ were $36 \mathrm{~kg}$ and $87 \mathrm{~kg} \mathrm{~N} / \mathrm{ha}$ respectively for a $0-30 \mathrm{~cm}$ depth sample taken in late winter. Moddus was applied at three rates, 0.8, 1.6 and $2.4 \mathrm{l} / \mathrm{ha}$, at Zadoks GS 32 on 25 October.

The early (standard) closing on 25 September was achieved with sheep when all plots were grazed. The mid- (5 October) and late- (15 October) closing were achieved by mowing. At the mid-closing, both midand late-closed plots were defoliated by mowing at between 60 and $70 \mathrm{~mm}$ above ground level. Crop mass at each closing was measured by cutting three quadrates $(0.25$ $\mathrm{m}^{2}$ ). Moddus was applied at five rates, 0 , $0.8,1.6,2.4$ and $3.2 \mathrm{l} / \mathrm{ha}$ on each closing date. Application was at Zadoks GS 32 at between 32 and 24 days after closing. The cultivar was 'Grasslands Commando', which has a similar flowering date to 'Grasslands Nui' perennial ryegrass.

\section{Results and Discussion \\ Rate trials}

Seed yield increased at a maximum rate up to approximately $1.6 \mathrm{l} / \mathrm{ha}$ (400 $\mathrm{g}$ a.i./ha) followed by a decreasing rate response (Figure 1) when relative seed yield data (untreated control equals $100 \%$ ) from ten experiments were combined. These data build on those presented by Rolston et al. (2004) where a similar response curve was shown for a single experiment. Increasing Moddus rates generally increased the 
number of seeds per spikelet at harvest which was directly related to seed yield (Figure 2). Reduced lodging and better solar radiation use in the upper canopy was associated with greater retention of developing seeds and less seed abortion, therefore providing greater seed production/ear. These results are supported by Hebblethwaite et al. (1978) and Griffith (2000) who both showed that when artificially supported during lodging perennial ryegrass produced significantly more seeds/ear.

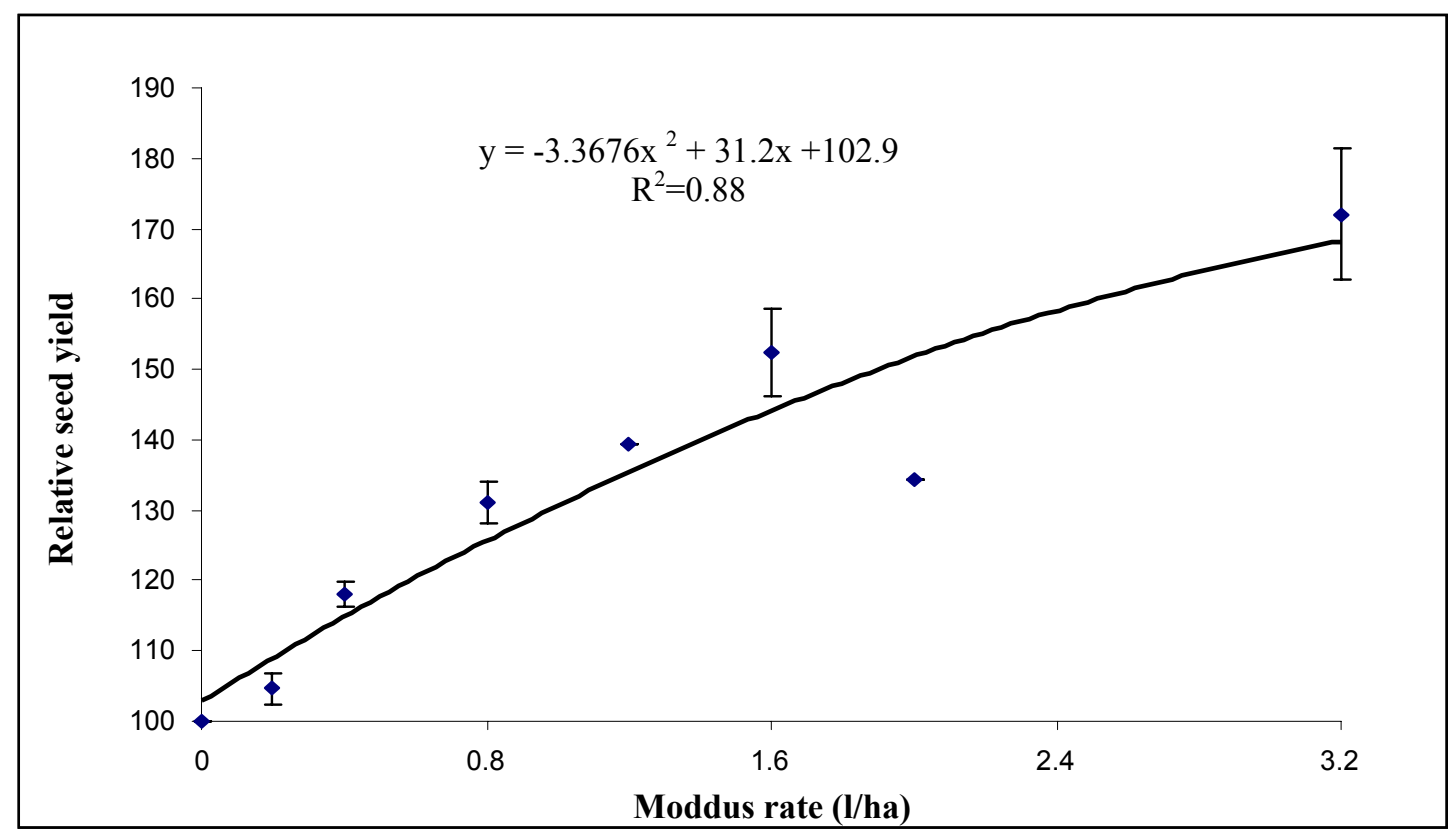

Figure 1 Perennial ryegrass seed yield response (relative to the control) to various application rates of Moddus plant growth regulator, average of 10 trials. Error bars = standard error of the mean. 


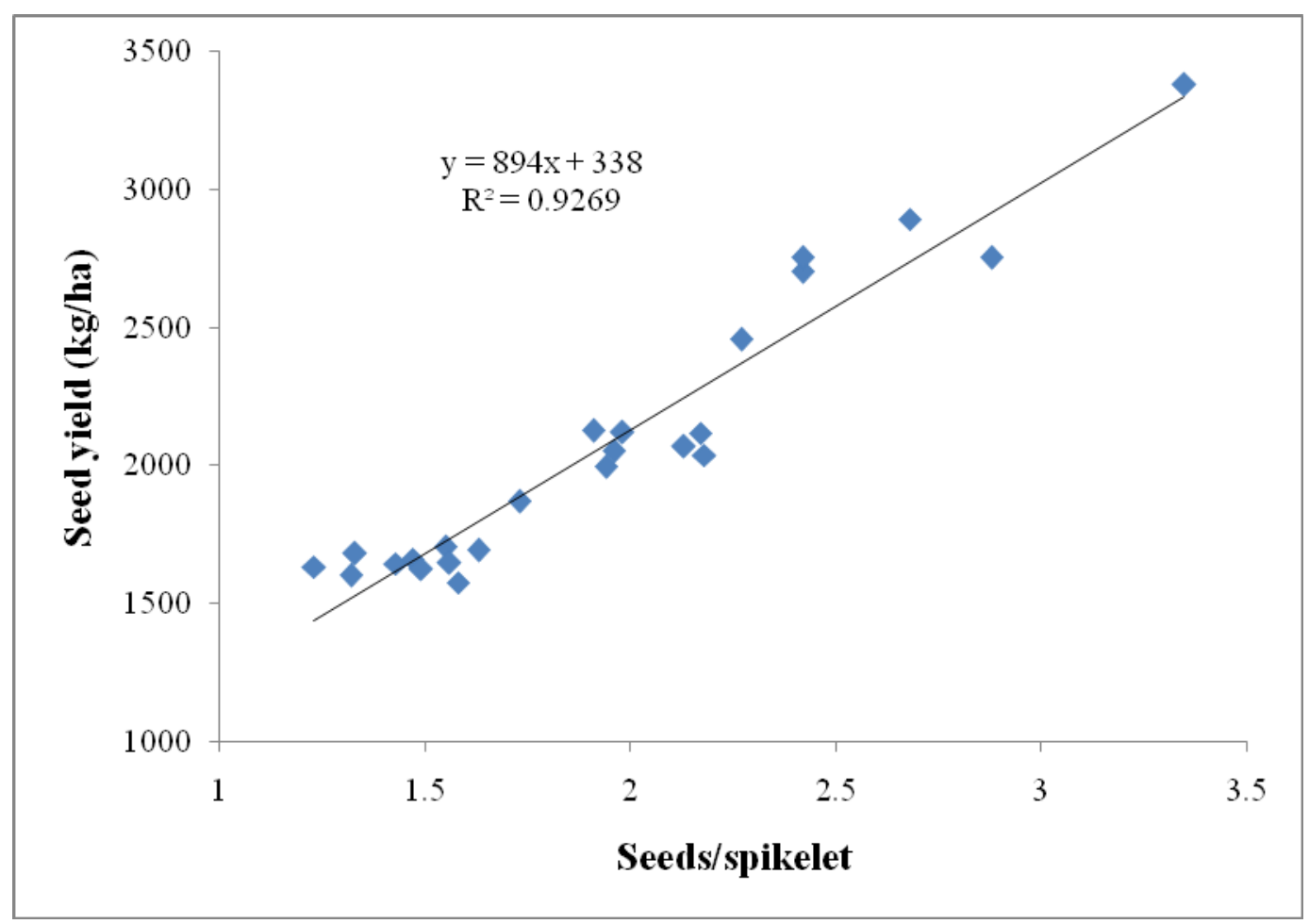

Figure 2 Relationship between seeds/spikelet at harvest and perennial ryegrass seed yield from five trials, 1999/2000 season.

\section{Nitrogen and Moddus interactions}

There was no interaction between Moddus rate $(0.8$ to $3.21 /$ ha $)$ and $\mathrm{N}$ rates $(\mathrm{P}<0.05)$. Thus increasing Moddus rate increased $(\mathrm{P}<0.05)$ average seed yield by $20 \%$, but did not alter the optimum $\mathrm{N}$ rate or the shape of the response curve (Figure 3). Seed yield increased up to an optimum (total N, applied + soil mineral $\mathrm{N}$ ) of approximately 150-190 $\mathrm{kg} \mathrm{N} / \mathrm{ha}$ depending on the model used for interpretation. Therefore the rate of Moddus applied should not alter the $\mathrm{N}$ rate used by growers. However Rolston et al. (2007b) showed an interaction when comparing nil versus Moddus treatments at various $\mathrm{N}$ application rates. Moddus increased the optimum $\mathrm{N}$ response rate from 50 to $150 \mathrm{~kg}$ $\mathrm{N} / \mathrm{ha}$ (irrigated) and from 150 to $200 \mathrm{~kg}$ $\mathrm{N} /$ ha (dryland).

Young et al. (2007) also showed that Moddus and $\mathrm{N}$ both increased final seed yield in perennial ryegrass but found no interaction between the two. This is in contrast to the response in creeping red fescue where there was an interaction $(\mathrm{P}<0.05)$ when $\mathrm{N}$ was applied to plots which were either treated or not treated with Moddus (Young et al. 2007). 


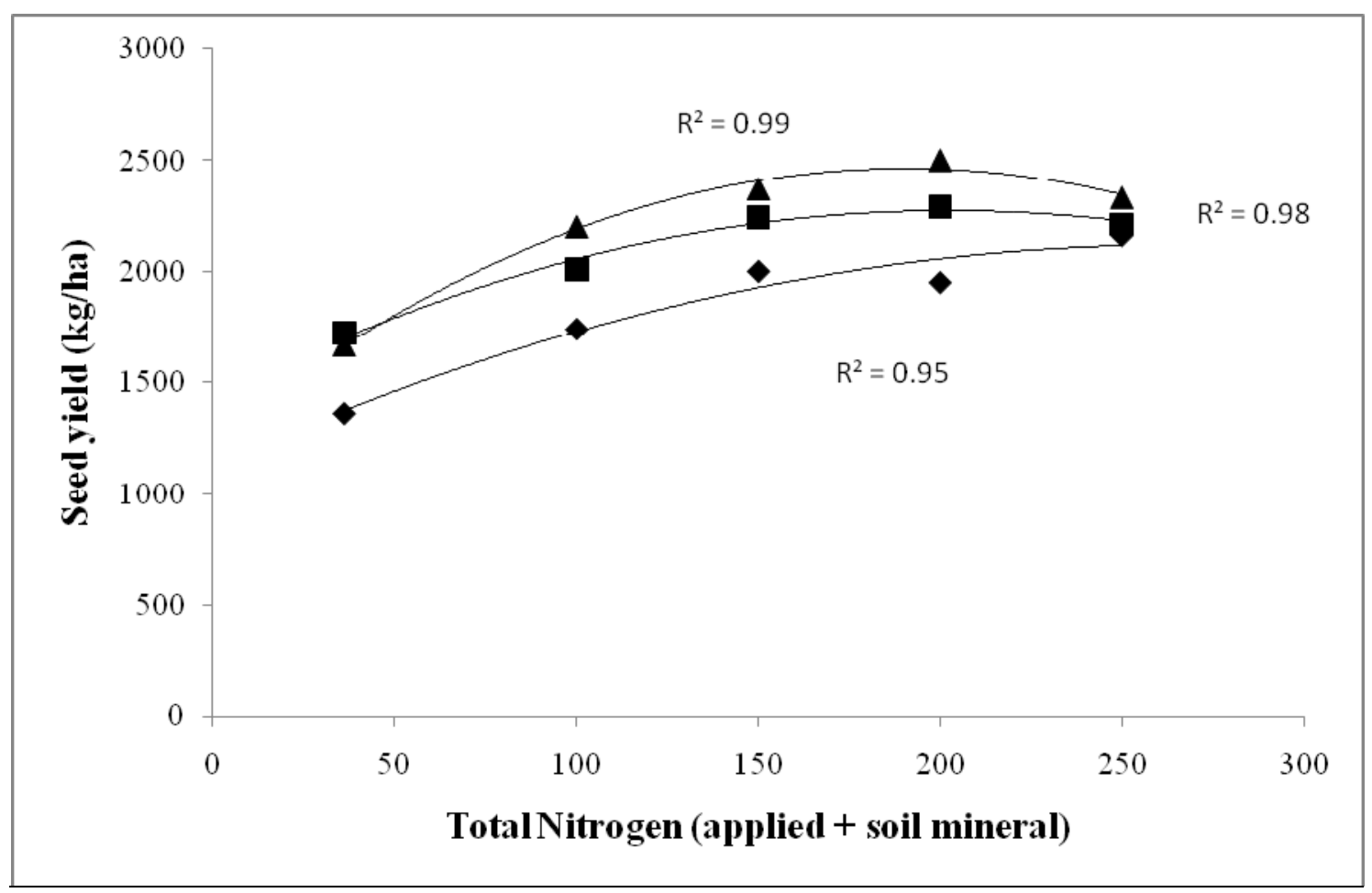

Figure 3 Perennial ryegrass seed yield response to three rates of Moddus plant growth regulator $(\boldsymbol{\nabla}=0.8 \mathrm{l} / \mathrm{ha}, \boldsymbol{\square}=1.6 \mathrm{l} / \mathrm{ha}$ and $\boldsymbol{\Delta}=2.4 \mathrm{l} / \mathrm{ha})$ at different nitrogen application rates.

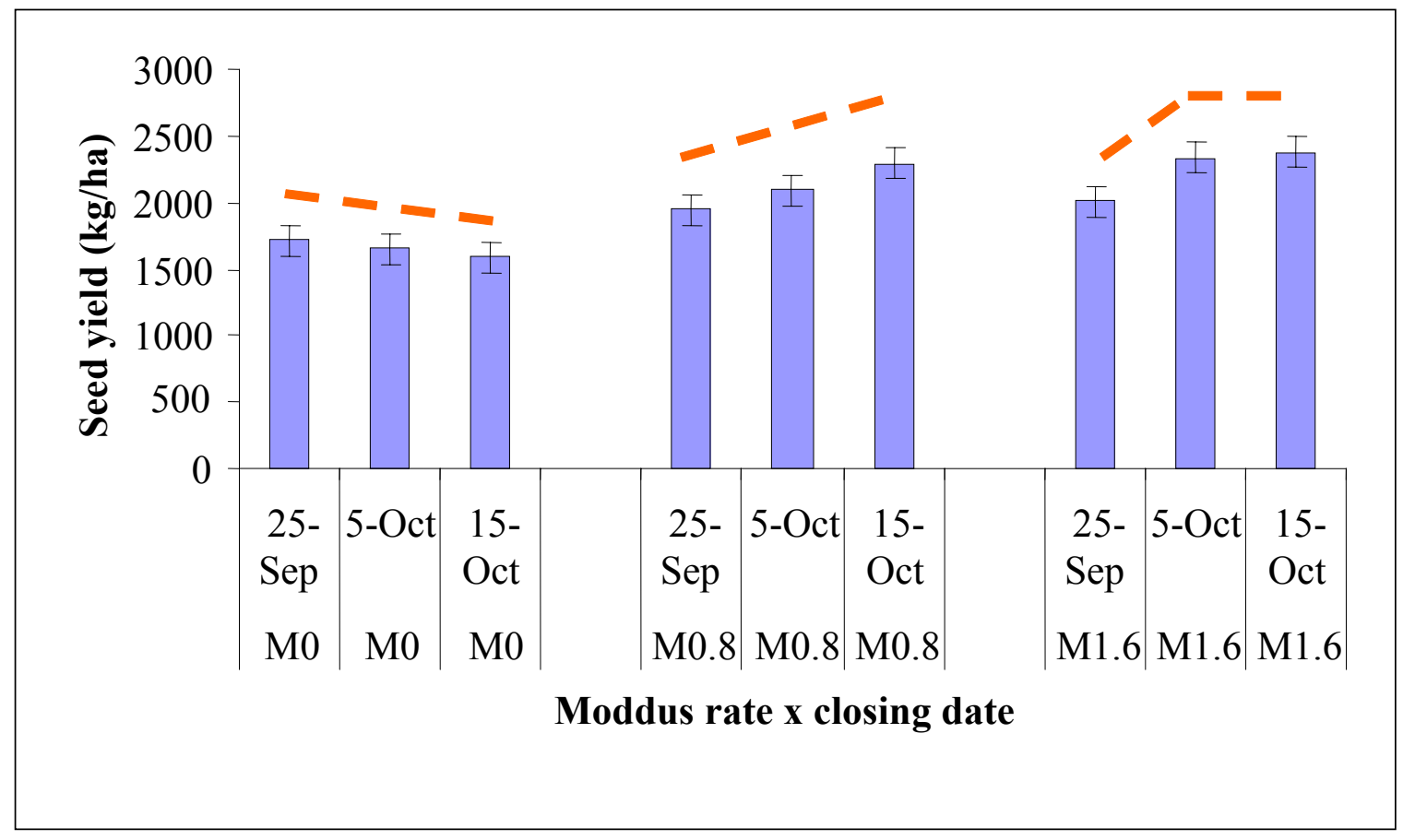

Figure 4 Interaction for perennial ryegrass seed among three closing dates and three Moddus rates. $\mathrm{LSD}_{0.05}$ error bars shown. 


\section{Closing date and Moddus interaction}

There was a Moddus by closing date interaction $(\mathrm{P}<0.05)$ (Figure 4). The nil Moddus treatments showed declining seed yield with later closing date $(-6 \mathrm{~kg}$ seed/day delay in closing). The optimum closing date for nil Moddus was 25 September, consistent with long-term best practice. However with Moddus the optimum closing date was equal to or greater than 10 days later compared to nil Moddus, with seed yield gains of 15 and $33 \mathrm{~kg} / \mathrm{ha} /$ day when closing was delayed. This is consistent with a Foundation for Arable Research (FAR) closing date trial in Methven (2006/07) where a later than expected optimum closing date (2 October) was identified for a dryland crop, cv. 'Grasslands Commando' that had $1.6 \mathrm{l} / \mathrm{ha}$ Moddus applied. Later closing resulted in similar yield increases from Moddus at lower application rates compared with earlier closing dates (Figure 5). Earlyclosing produced a linear $\left(\mathrm{R}^{2}=0.97\right)$ response to increasing Moddus rates (Figure 5a) with maximum seed yield achieved at 3.2 1/ha (highest application rate), consistent with historical response data (B.L. McCloy unpublished data 2000). Delayed closing resulted in similar maximum yields from reduced Moddus rates of 2.4 and 0.81 /ha for the 5 October and 15 October closings respectively. Responses at rates above these plateaued (Figure $5 \mathrm{~b}$ and $\mathrm{c}$ ). The highest final yields were still 158 and $144 \%$ greater than the untreated controls. The shape of the Moddus rate response curves changed with delayed closing which may be related to crop bulk at the time of application. Increasing bulk (DM/ha) at Moddus application increases the dilution of the applied product within the developing plant. Increased spring crop bulk inherently leads to greater risk of early crop lodging therefore reducing crop bulk through defoliation leads to lower PGR rates required to prevent lodging. These results have implications for growers trying to estimate the amount of PGR to apply to seed crops - especially when converted into $\$ /$ ha, including grazing value. This requires further investigation to confirm similar results across sites and cultivars.

\section{Lodging and photosynthetically active radiation (PAR)}

There were large differences in lodging between closing dates and Moddus rates. The early-closed nil Moddus had $>50 \%$ lodging pre-anthesis. Delaying closing delayed the onset of severe lodging $(>50 \%)$ by 7 days for each of the two closing dates. Only the lowest rate of Moddus (0.8 1/ha) was required to stop the late-closed crop from lodging, compared with 1.6 to $2.4 \mathrm{l} / \mathrm{ha}$ for the mid-closing date and $3.2 \mathrm{l} / \mathrm{ha}$ for early-closing. Lodging is directly related to the interception of solar radiation and treatments which prevented lodging had the highest seed yield. Lodging reduces seed yield in monocots through a combination of reduced radiation use efficiency, reduced green leaf retention, increased disease and secondary vegetative growth (Hay and Walker 1989). Lodging before anthesis can affect pollination and may affect the amount of carbohydrate available for seed growth (Griffith 2000). Moddus reduces lodging through a reduction in stem length (Borm \& van den Berg 2008), attributed to reduced internode length (FAR, unpublished data 2008).

Photosynthetically active radiation, measured at the flag leaf, was associated with the amount of lodging which had occurred. Later closing and increased Moddus rate generally had higher incoming PAR at the flag leaf level (Table 1). 


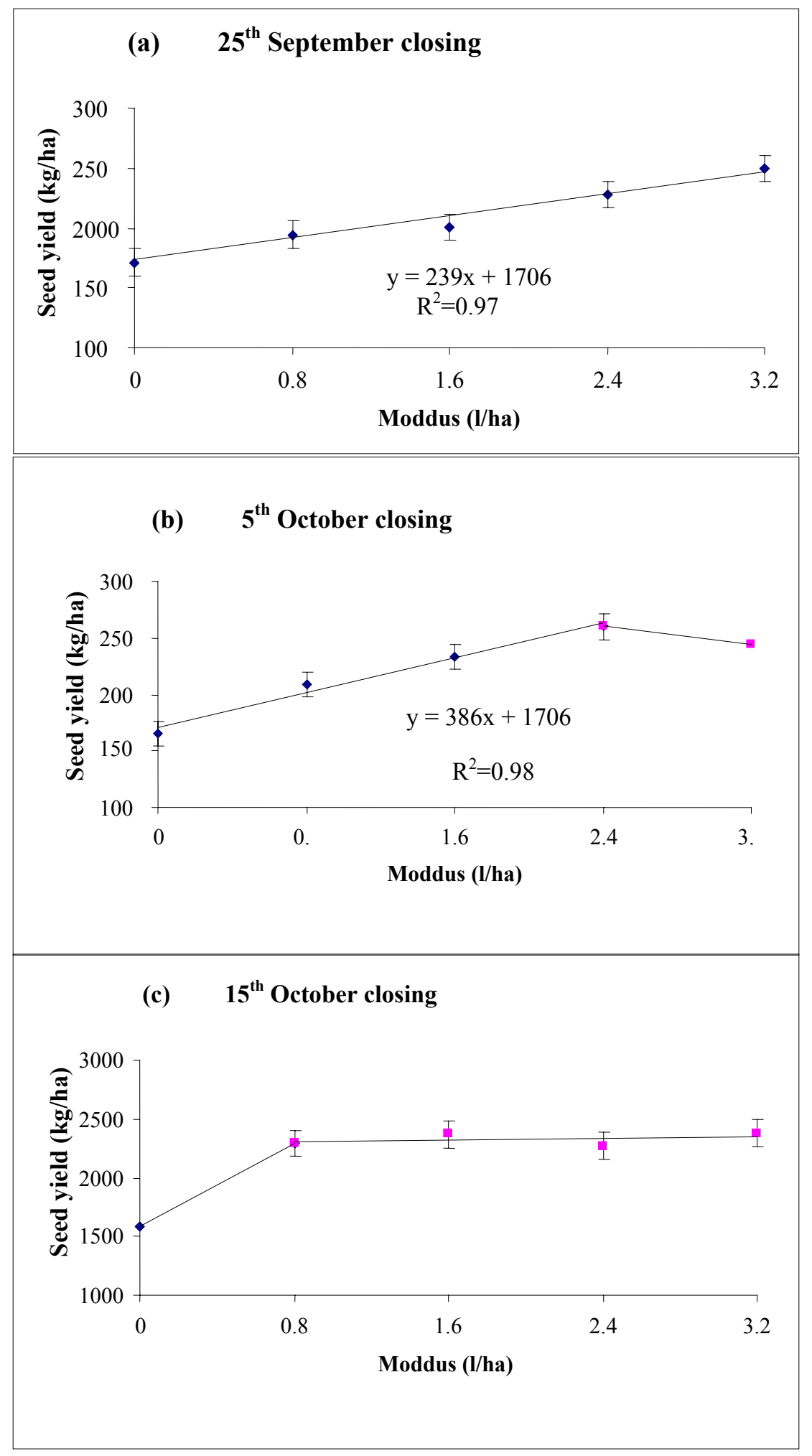

Figure 5 Moddus response at three closing dates, (a) 25 September, (b) 5 October (equation describes the line fitted to the yield response between 0 and 2.4 1/ha Moddus) and (c) 15 October. 
Table 1 Photosynthetically active radiation (PAR) at the flag leaf as a percentage of above canopy PAR on 7 December.

\begin{tabular}{ccccc}
\hline Moddus (1/ha) & early- & $\begin{array}{c}\text { Closing } \\
\text { mid- }\end{array}$ & late- & Average \\
\hline 0 & 9 & 6 & 12 & 10 \\
0.8 & 9 & 8 & 13 & 10 \\
1.6 & 9 & 20 & 28 & 19 \\
2.4 & 17 & 21 & 26 & 22 \\
3.2 & 19 & 15 & 25 & 20 \\
\hline Average & 13 & 14 & 21 & 16 \\
\hline LSD 5\% (Closing, F-value $\mathrm{P}=0.03)=6$ & & \\
LSD 5\% (Modus, F-value $\mathrm{P}=0.006)=8$ &
\end{tabular}

Table 2 Changes in harvest index for various Moddus rates and closing dates, cultivar Commando, Methven 2007/08.

\begin{tabular}{ccccccc}
\hline & \multicolumn{7}{c}{ Moddus rate $1 / \mathrm{ha}$} \\
Closing date & 0 & 0.8 & 1.6 & 2.4 & 3.2 & Average \\
\hline early- & 13.4 & 14.6 & 15.6 & 17.3 & 17.2 & $15.6 \mathrm{~b}$ \\
late- & 14.6 & 18.0 & $\mathbf{2 0 . 0}$ & $\mathbf{1 8 . 7}$ & $\mathbf{2 0 . 7}$ & $18.4 \mathrm{a}$ \\
mid- & 11.1 & 15.5 & 17.0 & $\mathbf{1 9 . 6}$ & 17.6 & $16.2 \mathrm{~b}$ \\
\hline Average & $13.0 \mathrm{c}$ & $16.1 \mathrm{~b}$ & $17.5 \mathrm{ab}$ & $18.5 \mathrm{a}$ & $18.5 \mathrm{a}$ & 16.7 \\
\hline
\end{tabular}

LSD 5\% (Closing, F-value $\mathrm{P}<0.001)=1.1$

LSD 5\% (Moddus, F-value $\mathrm{P}<0.001)=1.4$

LSD 5\% (C x M, F-value $\mathrm{P}<0.080)=2.4$

Note: Main effect values with the same letter are not significantly different. Treatment effects in bold are not significantly different from the highest values.

\section{Harvest Index (HI)}

It is common for $\mathrm{HI}$ to range from 10 to $20 \%$ in perennial ryegrass (FAR, unpublished data). Increasing Moddus rates increased HI, whereas closing date results showed no consistent trends (Table 2). The application of Moddus increased HI through increasing seeds/spikelet (data not presented) without reducing the biomass produced, i.e., a shortening and thickening of the stem, as also supported by Young et al. (2007).

\section{Yield component changes}

Moddus treatments had higher seed head numbers $\left(2,320\right.$ to 2,560 heads $\left./ \mathrm{m}^{2}\right)$ compared with nil Moddus (average 1,950 heads $/ \mathrm{m}^{2}$ ). Mid- and late-closed treatments had more seed heads (average 2,300 and 2,880 heads $/ \mathrm{m}^{2}$ respectively) than the earlyclosed treatments $\left(1,900\right.$ heads $\left./ \mathrm{m}^{2}\right)$. It is not clear whether Moddus caused more seed heads to be released or better seed head survival. The latter is a more plausible explanation because stem elongation was well underway (2 nodes visible) when Moddus was applied. Borm and van den Berg (2008) showed an increase in head numbers from the application of Moddus above $0.8 \mathrm{l} / \mathrm{ha}$ when applied to perennial ryegrass in the Netherlands.

\section{Thousand seed weight (TSW)}

There were small but significant $(\mathrm{P}<0.05)$ effects of treatments on TSW. The lateclosed treatment had lower TSW than the early-closed treatment (1.81 and $2.01 \mathrm{~g}$ respectively), while the mid-closing date $(1.88 \mathrm{~g})$ was not different from either the early- or late-closing date. There was a trend for increased Moddus rates to decrease TSW 
but this was not significant. In other Moddus trials TSW has decreased or remained unchanged (FAR, unpublished data).

\section{Harvested seeds/spikelet}

The percentage seed recovery, defined as conversion of fertile florets (developing seeds) to saleable seed, increased from $49 \%$ up to $60 \%$ as Moddus rate increased from 0 to $1.6 \mathrm{l} / \mathrm{ha}$ (Figure 6 ). There was a trend for increasing Moddus rate to result in more seeds per spikelet being harvested, increasing from 2.0 to 2.3 or greater seeds/spikelet for Moddus applied at 0 and $\geq 1.61 /$ ha respectively. In this experiment the number of seeds/spikelet in the nil Moddus was higher than that found in other trials, and compares with 1.3 seeds/spikelet for nil Moddus compared with 2.2 seeds/spikelet for 1.2 1/ha Moddus (FAR trial H06/06).

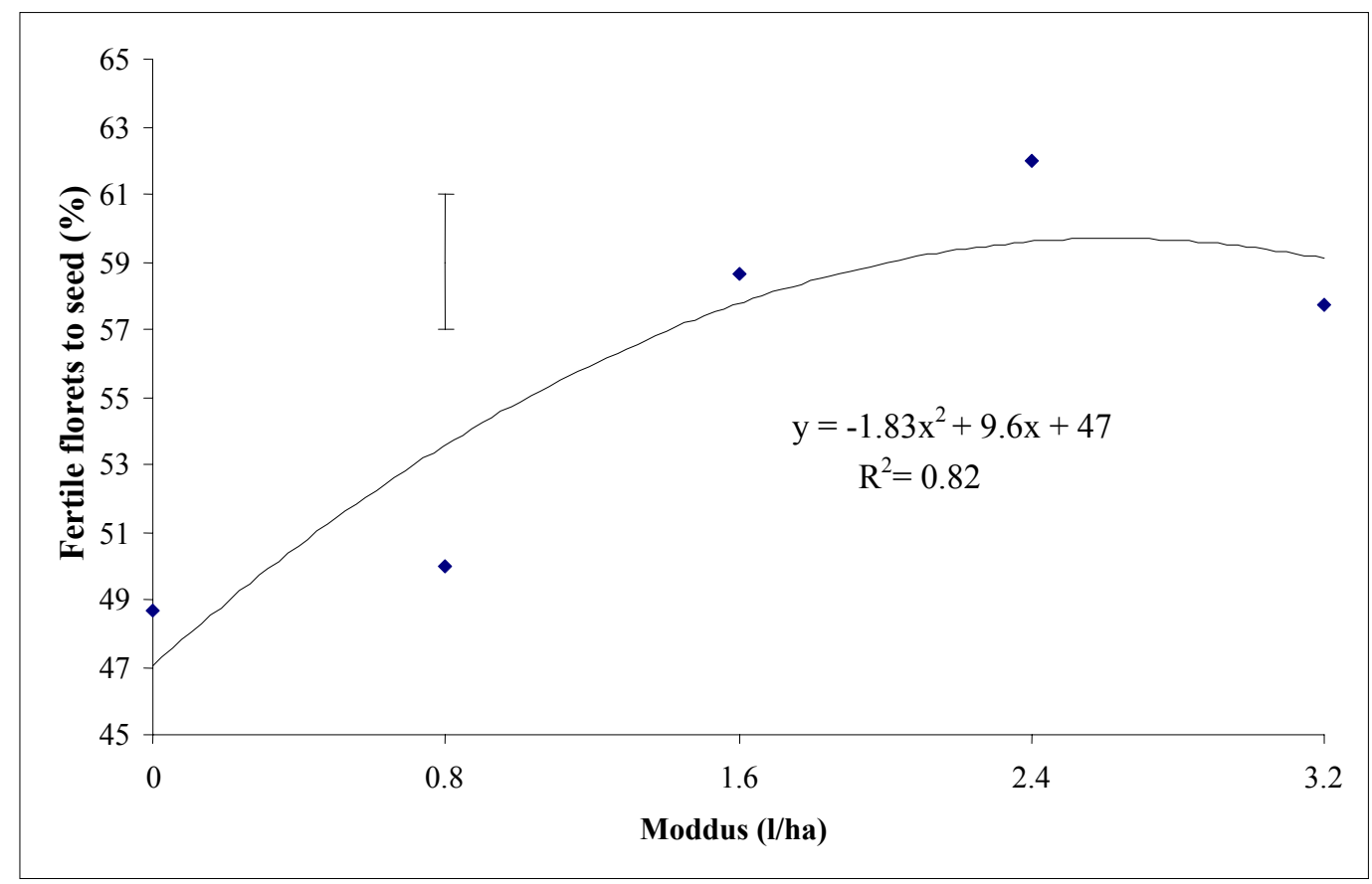

Figure 6 Effect of Moddus rates on the conversion of fertile florets to saleable seeds. Fertile florets are florets with a developing seed. Error bar is the SEM. 
In summary, increases in seed yield from the application of Moddus are through increases in harvest index and better dry matter partitioning. Changes in harvest components give greater seed heads $/ \mathrm{m}^{2}$ and increased seeds/spikelet at harvest. Increased seeds per spikelet are associated with reduced lodging and a better light environment during seed development. Nitrogen management should not change regardless of Moddus rate.

\section{Acknowledgements}

The authors thank the Foundation for Arable Research (FAR) and Syngenta for funding the reported experiments, staff at AgResearch Lincoln and NZArable who managed the experiments and seed growers who made fields available for the experiments. Moddus ${ }^{\circledR}$ is a registered trademark of a Syngenta Group Company.

\section{References}

Borm, G.E.L.; van den Berg, W. 2008. Effects of the application rate and time of the growth regulator trinexapac-ethyl in seed crops of Lolium perenne $\mathrm{L}$. in relation to spring nitrogen rate. Field Crop Research 105: 182-192.

Chastain, T. G.; Young III, W.C.; Garbacik, C.J.; Silberstein, T.B. 2003. Seed partitioning and yield responses to trinexapac-ethyl in perennial ryegrass. pp. 104-108. In: Proceedings of the $5^{\text {th }}$ International Herbage Seed Conference.

Griffith, S.M. 2000. Changes in dry matter, carbohydrate and seed yield resulting from lodging in three temperate grass species. Annals of Botany 85: 675680.

Hampton, J.G. 1986. The effect of chlormequat chloride application on seed yield in perennial ryegrass (Lolium perenne L.). Journal of Applied Seed Production 4: 8-13.

Hampton, J.G.; Hebblethwaite, P.D. 1985. The effect of the growth regulator paclobutrazol (PP333) on the growth, development and yield of Lolium perenne grown for seed. Grass and Forage Science 40: 93101.

Hay, R.K.M.; Walker, A.J. 1989. An introduction to the physiology of crop yield. Longman Scientific and Technical, New York, United States of America. 292 pp.

Hebblethwaite, P.D.; Wright, D.; Noble, A. 1980. Some physiological aspects of seed yield in Lolium perenne L. pp. 71-90 In: Seed production. Ed. Hebbethwaite, P.D. Butterworths, London, United Kingdom.

Hebblethwaite, P.D.; Burbridge, A.; Wright, D. 1978. Lodging studies in Lolium perenne grown for seed. 1. Seed yield and seed yield components. Journal of Agricultural Science, Cambridge 90: 261-267.

Rademacher, W. 2000. Growth retardants: effects on gibberellins biosynthesis and other biosynthesis pathways. Annual Reviews Plant Physiology and Plant Molecular Biology 51: 501-531.

Rolston, M.P.; McCloy, B.L.; Pyke, N.B. 2004. Grass seed yields increased with plant growth regulators and fungicides. Proceedings of the New Zealand Grassland Association 66: 127-132.

Rolston, M.P.; Trethewey, J.; McCloy, B.L.; Chynoweth, R.J. 2007a. Achieving forage ryegrass seed yields of 3000 $\mathrm{kg} / \mathrm{ha}$ and limitations to higher yields. pp. 100-106. In: Proceedings of the $6^{\text {th }}$ International Herbage Seed Conference.

Rolston M.P.; McCloy B.L.; Trethewey J. 2007b. Nitrogen-Moddus interaction in perennial ryegrass seed production. Proceedings of the Agronomy Society of New Zealand 37: 37-44. 
Silberstein, T.B.; Young III, W.C.; Chastain, T. G.; Garbacik, C.J. 2003. Response of perennial ryegrass to spring nitrogen fertility and plant growth regulator applications. pp. 147-151. In: Proceedings of the $5^{\text {th }}$ International Herbage Seed Conference.

Young III, W.C.; Silberstein, T.B.; Chastain, T. G.; Garbacik, C.J. 2007. Response of creeping red fescue (Festuca ruba L.) and perennial ryegrass (Lolium perenne L.) to spring nitrogen fertility and plant growth regulator applications in Oregon. pp. 201-205. In: Proceedings of the $6^{\text {th }}$ International Herbage Seed Conference.

Zadoks, J.C.; Chang, T.T.; Konzak, C.F. 1974. A decimal code for growth stages of cereals. Weed Research 14: 415-421. 